SPORT - Science \& Practice, Vol. 11, №1, 2021, pp. 15-24.

Original scientific paper

\title{
IMPORTANCE OF SPORTS AND RECREATIONAL ACTIVITIES FOR PEOPLE WITH DISABILITIES ${ }^{12}$
}

\author{
UDC: 796.011.1-056.26(497.11) \\ https://doi.org/10.18485/snip.2021.11.1.en.3 \\ Sanela Slavković ${ }^{3}$ \\ Faculty of Medicine, Department of Special Education and Rehabilitation, \\ University of Novi Sad, Serbia \\ Sabina Klbeček \\ Faculty of Medicine, Department of Special Education and Rehabilitation, \\ University of Novi Sad, Serbia \\ Daniela Tamaš \\ Faculty of Medicine, Department of Special Education and Rehabilitation, \\ University of Novi Sad, Serbia
}

\begin{abstract}
The quality of life is a broad concept influenced by the physical health of an individual, their mental state, and the degree of independence, social relations and numerous variables from the environment. Sports and recreational activities can contribute to improving the quality of life of people with disabilities. The main goal of the survey is to determine the importance of sports and recreational activities for people with disabilities. The sample consists of 44 respondents, aged 18-63 (M=34.5) years. Respondents are engaged in various sports (competitive and recreational). Two questionnaires were used in the survey: the General Questionnaire (which contains questions on general socio-demographic data, as well as questions about training, motives for playing sports, the perception of the impact of sports on various aspects of an individual's life) and the Health Questionnaire (EQ-5D) which examines the health status of the general population and people with chronic diseases and/or disabilities. Based on the obtained results, it was found that people with disabilities perceive sport primarily as an opportunity for socializing and recreation, and half of the respondents view it as a profession. People with disabilities have motivation and desire to play sports and are aware of the positive outcomes that result from sports and recreational activities. The professional and scientific public could contribute to improving the conditions for them. It is necessary to open this topic and point out its importance so that a larger number of people with disabilities could have the opportunity to engage in a variety of sports and recreational activities.
\end{abstract}

Key words: sport, people with disabilities, health, motivation, the quality of life

1 Paper received: 17 March 2021, edited: 12 April 2021, accepted for publication: 12 April 2021

2 This paper is a part of the results obtained by the research conducted for the purposes of a final paper: Klbeček, S. (2020). Importance of sports and recreational activities for people with disabilities (Final paper). Novi Sad: Faculty of Medicine, University of Novi Sad.

$3 \bowtie$ sanela.slavkovic@mf.uns.ac.rs 


\section{INTRODUCTION}

The application of sports and activities for people with disabilities plays a significant role during and after rehabilitation due to the proven positive effect on mental and motor abilities, as well as on the quality of life of this population (Kljajić et al., 2018).

Therefore, sports activities for people with disabilities can be crucial in preserving and improving health, but also in optimizing the remaining psychophysical abilities. From the psychological aspect, exercising provides a number of beneficial effects within psychological health care. Resistance to psychological problems is developed, as well as to the conflicts of everyday life. From the physical aspect, the level of general abilities increases, which provides greater independence and mobility. Sport affects all aspects that form an integral part of human health, especially when it comes to people with impaired psychophysical abilities. Therefore, sports recreation can be said to be the optimal form of activity that every society should provide to people with different degrees and types of disabilities (Bartoš, 2016). Also, for people with disabilities, sports and physical activity are factors that positively affect the overall quality of life, mental stability, motivation and self-confidence (Ivanović et al., 2010).

The positive effect of sports on the social participation of this population of citizens should not be forgotten. Through sports people with disabilities get the opportunity to be involved in social events, interact with other people and feel like they form a part of the community, which is the ultimate goal of rehabilitation (Petrinović, 2014). From the above mentioned, it can be concluded that sports activities are crucial for people with disabilities for their well-being in all respects, but unfortunately they are often prevented from engaging in any sport, even recreational activities (Ivanović et al., 2010). Given the listed advantages of sports, the development of sports and the participation of this population in that type of activity should be ensured by the system (Kljajic et al., 2018).

The way in which public policies could contribute to the development of sports is, first of all, the removal of architectural barriers, which require special attention because they are often the main reason for the exclusion of people with disabilities from the sphere of sports. The realization of sports activities for people with disabilities requires accessibility of sports facilities and sports venues, the procurement of sports equipment, financial support for the procurement of sports aids and assistive technology, as well as education of professional staff. However, the problem becomes more complex when attention is paid to the need to adapt inaccessible paths, local public transport, parking spaces, etc. (Kljajic et al., 2018). These obstacles could be overcome by familiarizing local communities with the existing issues, introducing them to the principles of universal design, as well as promoting the contribution of sports and recreational activities for people with disabilities (Petrinović, 2014).

The main aim of this study is to determine the importance of sports and recreational activities for people with disabilities.

In line with the general aim, specific aims have been defined:

1. To determine whether the respondents view sport as a pastime, obligation, recreation, socializing, therapy or profession;

2. To determine what motivates the respondents to do sports;

3. To determine whether the respondents have a subjective feeling that there has been an improvement in their physical and mental health due to playing sports;

4. To determine the perception of health of people with disabilities who engage in sports activities;

Based on the set aims, the following hypotheses were derived:

1. The largest number of respondents see sports as entertainment, socializing or therapy;

2. The primary motive for engaging in sports for people with disabilities is socializing and social contact that respondents achieve through sports;

3. Most respondents believe that there has been an improvement in the physical aspect of health thanks to their engagement in sports activities;

4. The perception of the health of people with disabilities in all five surveyed domains was assessed, and the respondents reported that they do not have problems in the mentioned areas. 


\section{METHOD}

\section{Sample}

The study involved 44 people with disabilities, aged 18 to $63(\mathrm{M}=34.5)$. People with disabilities who are members of sports organizations of people with disabilities in the Republic of Serbia were included in the survey with the consent of the heads of the organizations.

The basic criterion for inclusion was that the person had engaged in sports activities for at least six months and the presence of a congenital or acquired disability. Respondents who do sports recreationally and professionally had the opportunity to participate in the survey.

\section{Instruments}

The following instruments were used for data collection purposes:

\section{General questionnaire}

A general questionnaire was created for data collection purposes. It consisted of two segments. The first part contained socio-demographic data (gender, age, place of residence, marital status, employment status, type of disability). The second part included questions in which respondents marked statements about the importance of sports and recreational activities for them (type of sport, training frequency, accessibility, and information regarding their sports association) as well as questions about the impact of sports and recreational activities on different aspects of life.

\section{EQ-5D questionnaire}

EQ-5D-3L is a standard health status assessment measure developed by a European quality of life group EuroQolGroup (Finch et al., 2019) as a simple, general health assessment measure. The questionnaire describes the health of the general population, as well as people with chronic diseases and disabilities. Several versions of the questionnaire are available (EQ-5D-5L, EQ-5D-3L, EQ-5D-Y). The questionnaires have been translated into a number of languages, including Serbian. Completing the questionnaire is not demanding (it takes up to five minutes to complete) and it represents a simple description of the health status profile. It includes five dimensions: mobility, self-care, usual activities, pain/discomfort and anxiety/depression, which are assessed on a three-point scale: no problems, moderate problems, severe problems.

\section{Statistical data processing}

Data obtained by descriptive statistical processing will be presented in tables and graphs.

\section{RESULTS}

A total of 44 respondents participated in the survey, of which 32 were men (72.7\%) and 12 were women (27.3\%). Regarding the place of residence, $37(84.1 \%)$ respondents came from a city, and only $7(15.9 \%)$ respondents lived in the countryside. The number of respondents who were married was $16(36.4 \%)$, six $(13.6 \%)$ of them were in a relationship and 18 (40.9\%) respondents were single.

Observing the employment status of the respondents, the largest number of them was retired - 18 (40.9\%), $11(25 \%)$ of them had the status of students, another $11(25 \%)$ respondents were unemployed, and only four (9.1\%) respondents were employed.

Table 1 presents the impairment, disease or condition that led to the disability of the people who participated in the survey. 
Table 1. Disability of the respondents

\begin{tabular}{lcc}
\hline & NUMBER OF PEOPLE & $\%$ \\
\hline Paraplegia/paresis & 15 & 34,1 \\
\hline Hemiplegia/paresis & 4 & 9,1 \\
\hline Quadriplegia/paresis & 2 & 4,5 \\
\hline Muscular dystrophy & 2 & 4,5 \\
\hline Cerebral paralysis & 1 & 2,3 \\
\hline Multiple sclerosis & 1 & 2,3 \\
\hline Amputation of one or more limbs & 9 & 20,5 \\
\hline Visual impairment & 6 & 13,6 \\
\hline Intellectual disability & 2 & 4,5 \\
\hline Autism & 1 & 2,3 \\
\hline Angelman syndrome & 1 & 2,3 \\
\hline TOTAL & 44 & 100 \\
\hline
\end{tabular}

Table 2 presents the results of the General Health Questionnaire (EQ-5D), which examines five areas of functioning.

Table 2. Health questionnaire

\begin{tabular}{lccc}
\hline & No problems & Moderate problems & Severe problems \\
\hline 1. Mobility & $18(40,9 \%)$ & $25(56,8 \%)$ & $1(2,3 \%)$ \\
\hline 2. Self care & $36(81,8 \%)$ & $8(18,2 \%)$ & 0 \\
\hline $\begin{array}{l}\text { 3. Usual activities } \\
\text { (Work, studying, homework...) }\end{array}$ & $28(63,6 \%)$ & $15(34,1 \%)$ & $1(2,3 \%)$ \\
\hline 4. Pain/discomfort & $23(52,3 \%)$ & $19(43,2 \%)$ & $2(4,5 \%)$ \\
\hline 5. Anxiety/depression & $36(81,8 \%)$ & $8(18,2 \%)$ & 0 \\
\hline
\end{tabular}

Based on the obtained results, a hypothesis can be adopted, which states that the perception of the health of people with disabilities in all five surveyed domains was assessed in such a way that the respondents had reported that they had not faced problems in these areas.

The representation of the number of people engaged in certain sports is presented in Table 3 .

Table 3. Representation of sports that respondents engage in

\begin{tabular}{lcl}
\hline TYPE OF SPORT & NUMBER OF PEOPLE & $\%$ \\
\hline Table tennis & 13 & 26 \\
\hline Wheelchair basketball & 9 & 18 \\
\hline Swimming & 8 & 16 \\
\hline Athletics (running, javelin) & 5 & 10 \\
\hline Taekwondo & 3 & 6 \\
\hline Shooting & 3 & 6 \\
\hline Sitting volleyball & 2 & 4 \\
\hline Boccia & 1 & 2 \\
\hline Fishing & 1 & 2 \\
\hline Goalball & 1 & 2 \\
\hline Cycling & 1 & 2 \\
\hline Karate & 1 & 2 \\
\hline Gym & 1 & 2 \\
\hline Fitness & 1 & 2 \\
\hline
\end{tabular}


Based on Table 3, it can be seen that most sports, i.e. 12 sports are individual, and only two are team sports (wheelchair basketball and sitting volleyball). It can be concluded that the largest number of respondents, 39 (78\%) of them do individual sports, and $11(22 \%)$ play team sports.

In the next part of the research, the issues related to the training of people with disabilities were discussed, including the ways in which they do sports, the difficulties they encounter during their training sessions, how they observe their sports and recreational activities, and what motivates them to do sports.

When asked whether they can come to training sessions on their own, $36(81.8 \%)$ people with disabilities answered that they come to training sessions on their own, and 7 respondents $(15.9 \%)$ that they do not come to training sessions on their own. One respondent (2.3\%) occasionally comes to training sessions on his/her own.

When asked if they encounter any kind of obstacle (curbs and potholes, narrow passages and paths, unadapted public transport, etc.) on their way to their training grounds, a total of 26 respondents (59.1\%) answered that this was not the case, and the rest of the respondents 18 (40.9\%) answered that they encounter barriers (one or more) when coming to training.

When asked whether people with disabilities prepare for training on their own, i.e. whether they change clothes and pack equipment independently, as many as $40(90.9 \%)$ respondents answered that they perform the above actions independently, and 4 people (9.1\%) stated that they do not do it on their own.

Graph 1 shows whether the respondents with disabilities engage in sports recreationally or professionally.

Graph 1. Type of sports engagement of people with disabilities

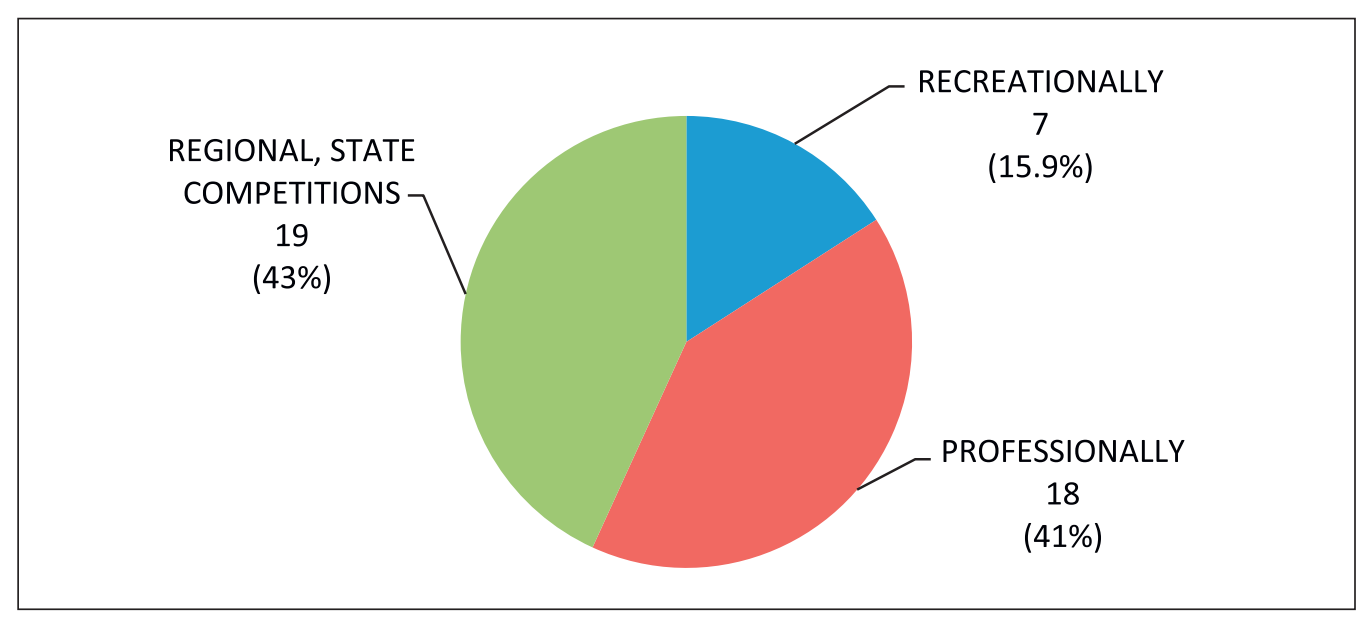

Graph 2 shows how people with disabilities view their engagement in sports, i.e. whether sport is a form of socializing, entertainment, recreation, whether sport is a form of therapy for them or they see sport as a profession. The respondents were able to give several answers to this question. The hypothesis that the majority of respondents perceive sports as entertainment, socializing or therapy has been confirmed.

Graph 2. How people with disabilities perceive their engagement in sport

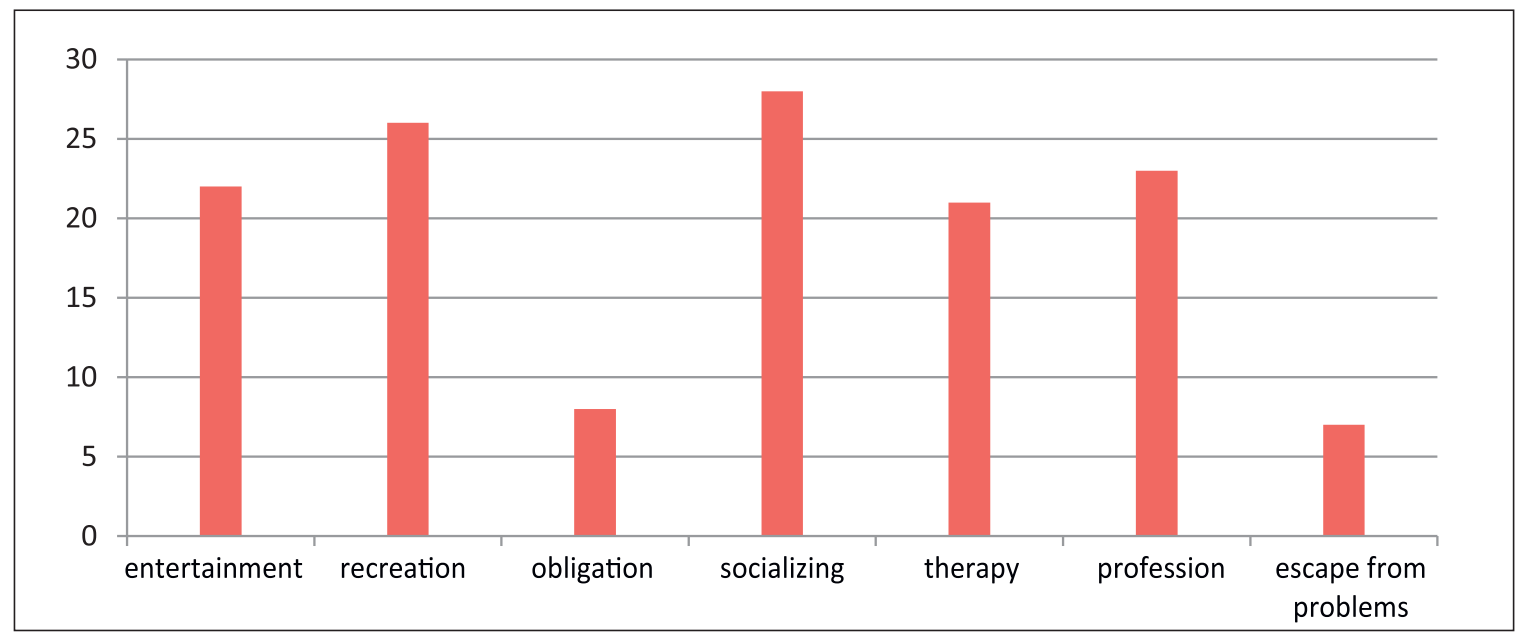


The main source of motivation for people with disabilities is shown in Graph 3, which shows the number of people who marked the given statement. They were able to provide multiple answers to this question.

Graph 3. Motivation for engaging in sports and recreational activities

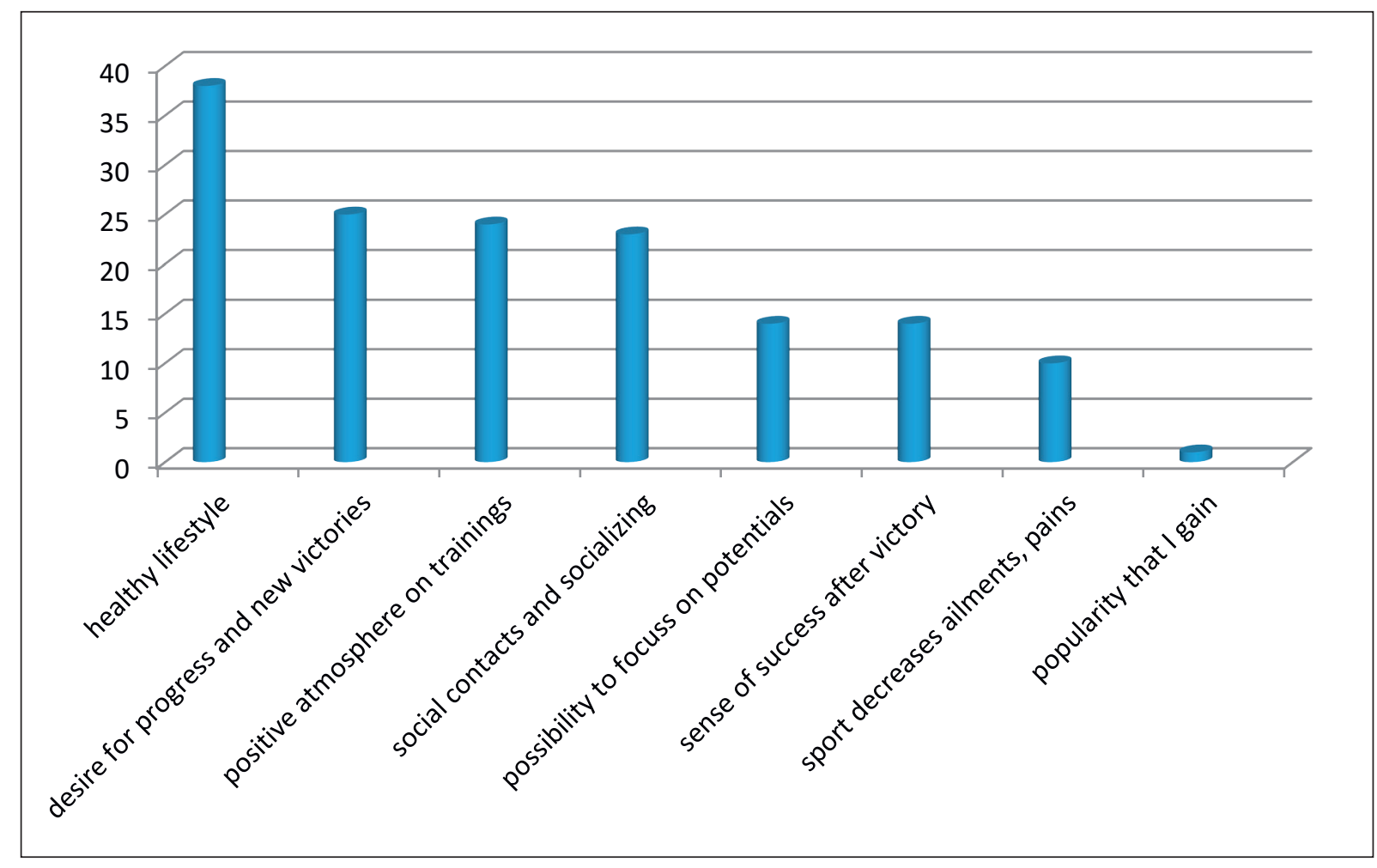

The hypothesis was that the primary motive for engagement in sports for people with disabilities is socializing and social contact that respondents make through sports. The presented results show that this hypothesis has partially been confirmed. However, the biggest source of motivation for this sample of respondents is leading a healthy lifestyle, while social contacts and socializing are in the fourth place.

The last part of the general questionnaire includes various questions that examine the adjustment of the equipment for the individual; the support that people receive during the training from their coach and other members of the club, but also from professionals; satisfaction with the achieved results; the overall contribution of sport to the quality of life of people with disabilities: the impact on physical and mental health, socialization, personal development and advancement.

Table 4 shows the number of answers to every question individually. The respondents answered the questions in relation to the extent to which they agree with the given statements, on a scale from 1 to 5 ( 1 - I do not agree at all; 2 - I do not agree; 3 - I partly agree; 4 - I agree; 5 - I completely agree).

Table 4. Number of answers to questions related to training condition, support, contribution of sports in various domains in life

\begin{tabular}{|c|c|c|c|c|c|c|}
\hline \multirow{2}{*}{\multicolumn{2}{|c|}{ QUESTION }} & \multicolumn{5}{|c|}{ LEVEL OF AGREEMENT } \\
\hline & & 1 & 2 & 3 & 4 & 5 \\
\hline 1. & $\begin{array}{l}\text { Conditions, equipment and access to training sessions are } \\
\text { adjusted }\end{array}$ & 4 & 3 & 11 & 8 & 18 \\
\hline 2. & Satisfaction with sports results & 3 & 0 & 11 & 18 & 12 \\
\hline 3. & Support from the coach and other club members & 4 & 0 & 3 & 11 & 26 \\
\hline 4. & Support from a professional in sports activities & 7 & 4 & 6 & 12 & 15 \\
\hline 5. & $\begin{array}{l}\text { Successful balancing of all obligations during the day with } \\
\text { training sessions and competitions }\end{array}$ & 3 & 1 & 7 & 13 & 20 \\
\hline
\end{tabular}




\begin{tabular}{|c|c|c|c|c|c|c|}
\hline 6. & $\begin{array}{l}\text { Contribution of sports in creating a sense of personal value } \\
\text { and increasing self-confidence }\end{array}$ & 4 & 0 & 4 & 8 & 28 \\
\hline 7. & $\begin{array}{l}\text { Contribution of sports in increasing productivity during } \\
\text { everyday activities (family, school, work...) }\end{array}$ & 3 & 0 & 7 & 9 & 25 \\
\hline 8. & Sport led me to introduce additional healthy habits into life & 3 & 2 & 7 & 12 & 20 \\
\hline 9. & $\begin{array}{l}\text { Playing sports motivates me to constantly progress and } \\
\text { achieve better results }\end{array}$ & 3 & 1 & 3 & 15 & 22 \\
\hline 10. & Sport enables me to make new friends & 4 & 1 & 3 & 9 & 27 \\
\hline 11. & $\begin{array}{l}\text { Sport has allowed me to realize my strengths and push my } \\
\text { limits }\end{array}$ & 3 & 2 & 3 & 13 & 23 \\
\hline 12. & $\begin{array}{l}\text { While I am in training/competition I feel unstoppable and } \\
\text { strong }\end{array}$ & 4 & 1 & 7 & 18 & 14 \\
\hline 13. & $\begin{array}{l}\text { Playing sports helps me improve my mood, and get rid of } \\
\text { negative emotions }\end{array}$ & 4 & 0 & 6 & 9 & 25 \\
\hline 14. & Sport has a therapeutic effect on me & 4 & 1 & 4 & 16 & 19 \\
\hline 15. & $\begin{array}{l}\text { I feel that my physical health is better since I have been } \\
\text { playing sports }\end{array}$ & 4 & 0 & 2 & 12 & 26 \\
\hline 16. & $\begin{array}{l}\text { I feel that my mental health is better since I have been } \\
\text { playing sports }\end{array}$ & 5 & 0 & 7 & 9 & 23 \\
\hline 17. & Before playing sports I felt that my life was unfulfilled & 11 & 9 & 15 & 7 & 2 \\
\hline 18. & I estimate that sport has contributed to the quality of my life & 4 & 0 & 4 & 11 & 25 \\
\hline
\end{tabular}

It can be observed that a significant number of respondents agree with the statement that the conditions, equipment, access to trainings are adjusted, and only a few of respondents, i.e. 7, answered that they do not agree with the given statement.

Based on the provided answers, it can be concluded that the respondents are mostly satisfied with the support they receive from the coaches during their sports activities, while the support from the professionals is somewhat less present. A quarter of respondents answered that this type of support is completely absent.

The obtained results indicate that the contribution of sports in increasing self-confidence, personal value, motivation and improving mood is exceptional, and as many as 36 respondents estimate that their quality of life has significantly improved since they have been playing sports. Engaging in sports and recreational activities has enabled people with disabilities to make new friends and feel accepted in the team in which they train.

It is interesting to point out that in addition to playing sports, most respondents answered that they managed to balance these activities with other daily activities (e.g. housework, studying, family...).

Also, the respondents estimated that their mental and physical health had been significantly better since they had started doing sports and that sport had a therapeutic effect on them, which confirms the hypothesis that most respondents believed that there had been an improvement in the physical aspect of health while practising sports and recreational activities.

\section{DISCUSSION}

Based on the results of the conducted research, a notable difference can be seen in the number of surveyed men (32) and women (12). The cause of such a disproportionate number of surveyed men and women origins in both the cultural norms of the society and the personal beliefs of women that they have less developed abilities and predispositions to do sports compared to men. They more frequently have lower expectations and therefore do not set high goals when it comes to engaging in sports activities, they give up more easily and are not motivated to progress in case of failure (Eccles \& Harold, 1989).

Also, women face double discrimination when they choose to do sports, gender-based and disability-based discrimination. This is supported by the fact that in the Paralympics Games the number of female competitors is traditionally two to three times lower than that of male competitors (Olenik et al., 1995). Some of the barriers that 
stand in the way of women engaging in sports relate to the classification system that was often unfair to women, and the fact that women received less media attention, i.e. they were less "visible" in the world of sports than men. Nowadays women with disabilities are more valued and more involved in sports than before, but it is certainly necessary to work on raising the self-confidence and motivation of women to give various sports and recreational activities a try (Olenik et al., 1995).

A significantly larger number of the surveyed persons with disabilities engage in individual sports, i.e. out of 14 sports listed here only wheelchair basketball and sitting volleyball are team sports. Team sports generally require more movement, position changes, quick reactions, they require the ability to predict the opponent's next move, as well as a high level of cooperation with other team members. On the other hand, individual sports, such as swimming, archery, javelin, do not require athletes to move around too much, they involve predictable movements, and the athlete knows exactly what to do and when to do something. Based on these facts, it is easy to understand why people with disabilities choose to do individual rather than team sports (Di Russo et al., 2010).

This paper has presented a number of positive aspects that result from people with disabilities being engaged in sports, and they are reflected in many areas of life, from performing daily activities, improving physical and mental health, to achieving full social integration. According to responses from the General Health Questionnaire (EQ-5D), it can be observed that the persons with disabilities included in the survey did not indicate that they were largely depressed or upset. This data indicates the positive impact of sports on mental health. Based on their research, Gioia et al. (2005) state that sport significantly improves mental health, primarily by influencing the reduction of anxiety and depression.

Research that compares the impact of sports on the psychological well-being of people with and without disabilities (Bačanac et al., 2014) indicates that the psychological profiles of athletes with and without disabilities are very similar, which confirms that playing sports positively contributes to their psychological strength by making them equally ready to successfully accomplish high achievements in sports, just like athletes without disabilities. Engaging in sports had a positive effect, not only on the self-confidence and self-esteem of athletes with disabilities, but it also optimized their competitive anxiety and improved the overall psychological stress management skills (Bačanac et al., 2014).

Mental health will largely depend on the feeling of belonging, i.e. on the establishment of social relations, as well as friendships, which is also an important motive and factor for engaging in sports and recreational activities. Considering the fact that people with disabilities are often excluded from various social events and that their social contacts are limited, it is easy to understand why sport is an important motive for them. Through sport, people with disabilities get to know each other, talk about everyday topics and in that way realize that they are not lonely and that there is a team where they can feel accepted. In addition, through sports competitions, they become visible to people without disabilities and thus break down the existing prejudices against this population of citizens (Wilhite \& Shank, 2009).

The foundations of the development of sports for people with disabilities date back to the 19th century, when it was first practised through rehabilitation in clinical conditions with the aim of improving their health (Crnković \& Rukavina, 2013).

Bartoš (2016) emphasizes that engaging in sports activities has a direct effect on the body component of organism of people with disabilities. People with disabilities improve their strength, speed, coordination and flexibility, which are significantly impaired as a direct consequence of disability. Also, sport reduces the risk of developing secondary diseases, such as diabetes, cardiovascular disease and obesity (Jaarsma et. al., 2014).

The support that people with disabilities have while playing sports is extremely important. In addition to formal support, the importance of informal support from family, friends and the environmenxt must not be overlooked. There are different types of support that facilitate sports activities, for example: providing assistance during arrival at training and preparation for training; professional advisory of the athlete and their family; financial support (for the purchase of customized equipment, assistive technology, adaptation of space for movement); health and social support. Respondents in this survey estimate that they have a higher level of informal support, i.e. support from club members in relation to the support they receive from professionals. Professionals have an important role to play when it comes to sports for people with disabilities (Kasum, 2015). In addition to advising athletes on the dosage of training, the choice of adequate sport for the individual, they help people with disabilities to realize the importance and benefits of sports, and therefore encourage them to actively engage in sports.

Financial resources are in every area a limiting, and sometimes a decisive factor for the realization of activities. The sports system should contain resources which imply all material conditions that would enable the basic training 
and competition process in the sports system. Optimal material resources should be planned for the organization of sports competitions, but also for the development of recreational sports for people with disabilities. Material resources would be primarily directed to the construction of a facility, which would meet the organizational and training needs of athletes (Vukajlović \& Vukajlović, 2015).

Based on the results of this survey, it can be noticed that the respondents evaluated that their quality of life had become better since they had started doing sports. Sport in the function of improving the quality of life is a generally accepted and scientifically confirmed fact due to the multidimensional impact of physical activities on the subjective assessment of the quality of life of people with disabilities (Crnković \& Rukavina, 2013).

As the main sources of motivation for engaging in sports and recreational activities the respondents state the desire to lead a healthy lifestyle that is achieved through sports. Furthermore, the motives are also the desire for progress and new victories, a positive atmosphere at training and social contacts and socializing. However, a study conducted by De Pero et al. (2009) emphasizes improved health and well-being as a prime motive for people with disabilities to engage in sports. Other motivating factors mentioned in this study are the desire to socialize and belong to a team; and a desire to participate in competitions, achieve athletic results, and face challenges.

A survey conducted in Banja Luka (Vukajlović \& Vukajlović, 2015) indicates that the motivation to improve health occupies the first place, the need for socializing and social activity is in the second place, and very few respondents answered that their motive is the physical appearance they want to achieve through sports.

\section{CONCLUSION}

This survey presents a lot of positive aspects of sports activities for people with disabilities, with the greatest emphasis on the psychological, health and social benefits of sport. The results of the survey show that the respondents noticed that there had been an improvement in physical and mental health, as well as an improvement in the quality of life from the period when they had started to practise some kind of physical activity. It was determined that the respondents observed sports as an opportunity for socializing, recreation, which also represented one of the main motivating factors for them to do sports. Therefore, it is certain that people with disabilities have the motivation and desire to play sports and they are aware of the positive outcomes that arise from involvement in sports and recreational activities. However, the local community, professionals, and the social environment are not aware of this and therefore invest little resources and effort in creating the conditions to enable people with disabilities to engage in this type of activity. For this reason, it is necessary to open this topic and raise awareness of its importance in order to launch an initiative to adapt the conditions in this domain with the aim that more people with disabilities have the opportunity to engage in a variety of sports, either recreational or competitive.

\section{REFERENCES}

1. Bačanac, Lj., Milićević-Marinković, B., Kasum, G. \& Marinković, M. (2014). Osećanja takmičarske anksioznosti, samopouzdanja i psihološkog blagostanja vrhunskih sportista sa i bez invaliditeta - pilot istraživanje. Facta Universitatis - series: Physical Education and Sport, 12 (2), 59-70.

2. Bartoš, A. (2016). Sociološko-kineziološki pristup sportskoj rekreaciji u resocijalizaciji osoba sa invaliditetom. Media, culture and public relations, 7 (1), 71-78.

3. Crnković, I. \& Rukavina, M. (2013). Sport i unapređenje kvalitete života kod osoba s invaliditetom. Hrvatska revija za rehabilitacijska istraživanja, 49 (1), 12-24.

4. De Pero, R., Amici, S., Benvenuti, C., Minganti, C., Capranica, L. \& Pesce, C. (2009). Motivation for sport participation in older Italian athletes: the role of age, gender and competition level. Sport Science for Health, 5 (2), 61-69.

5. Di Russo, F., Bultrini, A., Brunelli, S., Delussu, A. S., Polidori, L., Taddei, F., Traballesi. M. \& Spinelli, D. (2010). Benefits of sports participation for executive function in disabled athletes. J Neurotrauma, 27 (12), 2309-19.

6. Eccles, J. S. \& Harold, R. D. (1991). Gender Difference in Sport Involvement: Applying the Eccles Expectancy-Value Model. Journal Applied Sport Psychology, 7-35. 
7. Finch, A. P., Brazier, J. E. \& Mukuria, C. (2019). Selecting Bolt-On Dimensions for the EQ-5D: Examining Their Contribution to Health-Related Quality of Life. Value Health, 50-61. doi: 10.1016/j.jval.2018.07.001. Epub 2018 Aug 16. PMID: 30661634.

8. Gioia, M. C., Cerasa, A., Di Lucente, L., Brunelli, S., Castellano, V. \& Traballesi, M. (2005). Psychological impact of sports activity in spinal cord injury patients. Scandinavian journal of medicine \& science in sports, $16(6), 412-416$.

9. Ivanović, L., Eminović, F., Potić, S. \& Potić, S. (2010). Sport i fizičke aktivnosti osoba sa invaliditetom. 3. Međunarodni simpozijum sporta i zdravlja, Tuzla; 1-9.

10. Jaarsma, E. A., Dijkstra, P. U., Geertzen, J. H. B. \& Dekker, R. (2014). Barriers and facilitators of sports participation for people with physical disabilities: A systematic review. Scandinavian journal of medicine \& science in sports, 871-881.

11. Kasum, G. (2015). Sport osoba sa invaliditetom: Značaj sportskih aktivnosti u procesu integracije osoba sa invaliditetom. Beograd: Fakultet sporta i fizičkog vaspitanja.

12. Kljajić, D., Eminović, F., Arsić, S. \& Trajkov, M. (2018). Sportske aktivnosti osoba sa invaliditetom i arhitektonske barijere. Zdravstvena zaštita, 47 (4), 16-24.

13. Olenik, L. M., Matthews, J. M. \& Steadward, R. D. (1995). Women and disability sport: unheard voices. Canadian Woman Studies Journal, 15 (4), 54-57.

14. Petrinović, L. (2014). Sport osoba sa invaliditetom. Poreč: 23. Ljetna škola kineziologa Republike Hrvatske, 47-56.

15. Vukajlović, B. \& Vukajlović, D. (2015). Sport i osobe sa invaliditetom u kontekstu lokalne zajednice. Naučnostručni časopis SVAROG, 397-408.

16. Wilhite, B. \& Shank, J. (2009). In praise of sport: Promoting sport participation as a mechanism of health among persons with a disability. Disability Health Journal, 116-127. 